J. Appl. Glycosci., 51, 341-344 (2004)

(C) 2004 The Japanese Society of Applied Glycoscience

Note

\title{
Galactosyllactoses in the Milk of Japanese Women: Changes in Concentration during the Course of Lactation
}

\author{
(Received April 21, 2004 ; Accepted June 9, 2004) \\ Wataru Sumiyoshi, ${ }^{1,2, *}$ Tadasu Urashima, ${ }^{1, * *}$ Tadashi Nakamura, ${ }^{1}$ Ikichi Arai, ${ }^{1}$ \\ Takashi Nagasawa, ${ }^{3}$ Tadao Saito, ${ }^{4}$ Norihiko Tsumura, ${ }^{5}$ Bing Wang, ${ }^{6}$ \\ Janette Brand-Miller, ${ }^{6}$ Yoko Watanabe ${ }^{7}$ and Kazumasa Kimura ${ }^{7}$ \\ ${ }^{1}$ Department of Bioresource Science, Obihiro University of Agriculture and Veterinary Medicine \\ (Inada-cho, Obihiro 080-8555, Japan) \\ ${ }^{2}$ Course of the Science of Bioresources, The United Graduate School of Agricultural Science Iwate University \\ (Ueda 3-chome, Morioka 020-8550, Japan) \\ ${ }^{3}$ Department of Agro-bioscience, Faculty of Agriculture, Iwate University (Ueda 3-chome, Morioka 020-8550, Japan) \\ ${ }^{4}$ Department of Bioproduction, Graduate School of Agriculture, Tohoku University \\ (1-1, Tsutsumidori-Amamiya machi, Aoba-ku, Sendai 981-8555, Japan) \\ ${ }^{5}$ Department of Obstetrics and Gynecology, Asahikawa City Hospital (Kinsei cho, Asahikawa 070-8610, Japan) \\ ${ }^{6}$ Human Nutrition Units, Department of Biochemistry, The University of Sydney (NSW, 2006, Australia) \\ ${ }^{7}$ YAKULT Central Institute for Microbiological Research (1796, Yaho, Kunitachi, Tokyo 186-8650, Japan)
}

\begin{abstract}
The concentrations of three galactosyllactoses found in the milk of 24 Japanese women were determined using normal phase high-performance liquid chromatography of the 2-aminopyridyl (PA) derivatives of the oligosaccharides. The milk was collected at $4,10,30$ and 100 days post partum. The concentration of 6'galactosyllactose ( $6^{\prime}-\mathrm{GL}$ ) was maximal at 4 days post partum, and then decreased, whereas the concentrations of $3^{\prime}$ - and $4^{\prime}$-galactosyllactose $\left(3^{\prime}-\mathrm{GL}\right.$ and $\left.4^{\prime}-\mathrm{GL}\right)$ did not change during the course of lactation. In human milk, $6^{\prime}$-GL was the main oligosaccharide among these galactosyllactoses at 4 days post partum, in contrast to bovine milk in which $3^{\prime}$-GL has been reported to be predominant. The concentrations of these galactosyllactoses in human milk were much lower than those reported for $2^{\prime}$-fucosyllacose, 3-fucosyllactose, lacto- $N$ fucopentaose I, II and III, and $3^{\prime}-$ and $6^{\prime}-N$-acetylneuraminyllactose.
\end{abstract}

Key words: human milk, galactosyllactose, pyridylamination

The milk oligosaccharides other than lactose are thought to have anti-infection effects against pathogenic bacteria or viruses in suckling babies, exerted either via a prebiotic effect in the colon or direct inhibition of the attachment of these pathogenic microorganisms to epithelial cells. $^{1,2)}$ It has been shown that human milk/colostrum contains a much higher amount of milk oligosaccharides than bovine mature milk, ${ }^{3)}$ suggesting that oligosaccharides derived from bovine milk should be added to milk formulas for human babies. However, it has not so yet been possible to extract sufficient quantities of human milk oligosaccharides such as 2'-fucosyllactose, 3fucosyllactose, and lacto- $N$-fucopentaose I, II and III from bovine milk at a reasonable cost.

Galactooligosaccharides (GOs) are produced commercially from lactose by the action of $\beta$-galactosidase. ${ }^{4-7)} \mathrm{A}$ Japanese milk products company has incorporated them into infant milk formulas in order to stimulate the growth of Bifidobacterium in the infant colon, since it is known that GOs administrated orally act as a growth factor for Bifidobacterium in the human intestinal tract. ${ }^{8.9)}$ GOs are thus used as prebiotics, even though it is not known

\footnotetext{
* Present address: Department of Functional Glycomics, Life Science Research Center, Kagawa University, 1750-1, Ikenobe, Miki-cho, Kita-gun, Kagawa 761-0793, Japan.

** Corresponding author (Tel. +81-155-49-5566, Fax. +81-15549-5577, E-mail: urashima@obihiro.ac.jp).
}

whether they inhibit the attachment of pathogenic microorganisms to the infant colon.

In view of the above, it is desirable to have data on the actual concentrations of galactooligosaccharides in human milk at several lactation periods, but this information has not, as yet, been available. The present study was designed to obtain such data by determining the concentrations of $\operatorname{Gal}(\beta 1-6) \mathrm{Gal}(\beta 1-4) \mathrm{Glc}\left(6^{\prime}-\mathrm{GL}\right), \quad \mathrm{Gal}(\beta 1-3) \mathrm{Gal}$ $(\beta 1-4) \mathrm{Glc}\left(3^{\prime}-\mathrm{GL}\right)$ and $\operatorname{Gal}(\beta 1-4) \mathrm{Gal}(\beta 1-4) \mathrm{Glc}\left(4^{\prime}-\mathrm{GL}\right)$ in human milk at $4,10,30$ and 100 days post partum. The results are compared with those obtained for bovine milk as reported in a previous study. ${ }^{10)}$

Milk samples ( 3 to $5 \mathrm{~mL}$ ) were collected at 4, 10, 30 and 100 days post partum from 24 Japanese women who had given birth at Obihiro Kosei General Hospital. The samples were stored as described previously. ${ }^{11)}$ The 2aminopyridyl (PA) derivatives of $3^{\prime}-\mathrm{GL}, 4^{\prime}-\mathrm{GL}$ and 6'-GL, and Oligomate ${ }^{\mathrm{TM}} 90$, which is a mixture of some galactooligosaccharides, were kindly provided by Yakult Central Institute for Microbiological Research (Tokyo, Japan). 2Aminopyridine was purchased from Wako Pure Chemical Co., Ltd., Japan. Borane-dimethylamine complex was purchased from Aldrich Chemical Co., USA, and panose $[\operatorname{Glc}(\alpha 1-6) \operatorname{Glc}(\alpha 1-4)$ Glc $]$ was from Sigma Aldrich Co., USA. All other chemicals were analytical of grade except for acetonitrile that was of HPLC grade.

Human milk oligosaccharide fractions were prepared 
with $1 \mathrm{~mL}$ milk using four-volume chloroform/methanol ( $2: 1, \mathrm{v} / \mathrm{v})$ extraction and successive gel filtration on a Bio Gel P-2 column as described previously. ${ }^{11)}$ In a test using Oligomate ${ }^{\mathrm{TM}} 90$, it was shown that GL eluted in the same position as peak 5 (see Fig. 1 in Ref. 11)) during gel filtration; peak 5 was therefore used for the quantification of GLs.

2-Aminopyridyl (PA) derivatisation of the oligosaccharides in peak 5 was performed using $1 / 4$ volumes of the fraction separated from $1 \mathrm{~mL}$ milk. The PA derivatives were prepared as described for the analysis of GOs in galactooligosaccharides manufactured by Yakult Co. as well as for the analysis of GLs in commercial bovine milk. ${ }^{10-12)}$ The $10 \mathrm{nmol}$ of panose were added as an internal standard into each sample. The recovery rate during the extraction and pyridylamination steps of the saccharide was measured in a control experiment using milk to which panose had been added.

The PA derivatives of GLs were quantified using normal phase HPLC. The analysis was performed with a TSK-GEL Amide-80 column $(\phi 4.6 \times 250 \mathrm{~mm}$, Tosoh, Japan) at $40^{\circ} \mathrm{C}$ in a column oven (CO-8020; Tosoh). The eluate was controlled by a multi-pump (CCMP-II; Tosoh) equipped with a CCP controller (PX-8020; Tosoh). A 15 $\mathrm{mM}$ potassium phosphate buffer $(\mathrm{pH}$ 5.2) in acetonitrile at ratios of $20: 80$ and $50: 50$ were used as solution $\mathrm{A}$ and solution $\mathrm{B}$, respectively. Elution was done at a flow rate of $1 \mathrm{~mL} / \mathrm{min}$ with a linear gradient from 0 to $80 \%$ of solution $\mathrm{B}$ for $80 \mathrm{~min}$. Detection was done with a MCPD3600 Photodiode Array Detector (Otsuka Electronics, Japan) by monitoring the absorption of the eluates at 310 nm. PA derivatives of $1 / 4$ volumes of the fraction of peak 5 separated from $1 \mathrm{~mL}$ milk were dissolved in 100 $\mu \mathrm{L}$ of water, followed by filtration through a DISMIC-13 CP membrane $(0.45 \mu \mathrm{m}$, cellulose acetate membrane; Advantec Toyo, Japan), and then $10 \mu \mathrm{L}$ was injected. PA derivatives of $6^{\prime}-, 3^{\prime}-$ and $4^{\prime}-\mathrm{GL}$ were each identified by comparison of the relative retention time of each peak with that of the standard internal panose and of the PA derivatives of authentic samples of GLs. The ratio of the peak area of each PA-labeled standard to that of internal panose was determined prior to the determination of the content of each GL oligosaccharide in the sample. The quantitative value for each PA derivative of GL was obtained by comparing each peak area with that of the internal panose. Quantitative values are expressed as mean concentrations $\pm S D$. The reproducibility of the peak area of each PA derivative of the standard was determined using relative standard deviations; determination of the content of each oligosaccharide content was performed three times.

Representative chromatograms (see Fig. 1 in Reference 11) on Bio Gel P-2 of carbohydrate fractions extracted from the milk at each lactation stage were shown in a previous paper. ${ }^{11)}$ Figure 1 shows a representative chromatogram of the normal phase HPLC of the PA derivatives of the component in peak 5 .

The reproducibilities of the peak areas of $3^{\prime}-, 4^{\prime}-$ and 6'GL were $1.1,1.9$ and $1.7 \%$, respectively, and the recovery rate measured in the control experiment using panose was $90.9 \pm 2.5 \%$.

Table 1 shows the mean concentration and standard deviation of each GL at each lactation period studied. The concentration of $3^{\prime}-\mathrm{GL}$ showed little or no change from 4 to 100 days post partum. On the other hand, the concentration of $6^{\prime}$-GL was highest at 4 days post partum, and then decreased during the course of lactation; its content became similar to that of $3^{\prime}-$ GL by 100 days post partum. $4^{\prime}$-GL was not detected in about a half of the samples of the GLs that were quantified in this study.

A comparison of the concentrations of GLs of human milk in this study and of bovine milk reported by Kimura et $a l .{ }^{10)}$ shows that bovine milk contains $3^{\prime}-\mathrm{GL}$ in preference to $6^{\prime}-\mathrm{GL}$, whereas the $3^{\prime}-$ and $6^{\prime}-\mathrm{GL}$ contents in human milk were similar at 100 days post partum. The concentration of 6'-GL was higher in human milk than in bo-
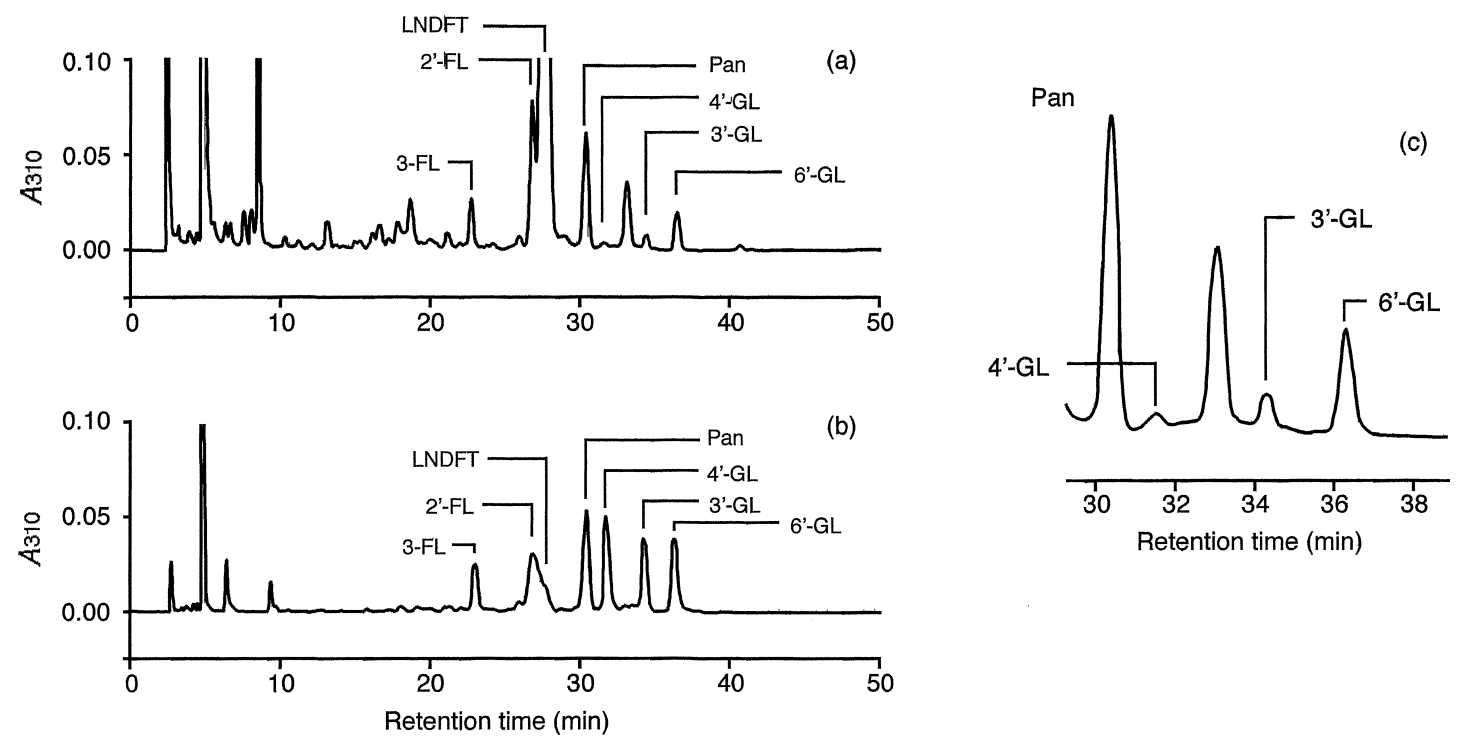

Fig. 1. High-performance liquid chromatogram of the PA derivatives of (a) the Bio Gel P-2 peak 5 separated from human milk at 4 days post partum and (b) standards.

Chromatogram (c) is an expanded chromatogram of (a). $A_{310}$, absorbance at $310 \mathrm{~nm}$. For other details, see Methods. GL, galactosyllactose; FL, fucosyllactose; LNDFT, lacto- $N$-difucotetraose; Pan, panose. 
Table 1. The concentration of each galactosyllactose in human milk collected at 4, 10, 30 and 100 days post partum.

\begin{tabular}{cccccc}
\hline & \multicolumn{5}{c}{ Days of lactation } \\
\cline { 2 - 5 } & $4(n=23)$ & $10(n=19)$ & $30(n=20)$ & $100(n=18)$ & Bovine milk** \\
\hline 3'-GL & $5.08 \pm 0.45$ & $5.01 \pm 0.77$ & $4.88 \pm 1.02$ & $4.84 \pm 0.48$ & $7.26-9.68$ \\
4'-GL & $1.43 \pm 1.52$ & $1.24 \pm 1.49$ & $1.34 \pm 1.53$ & $1.85 \pm 1.52$ & $1.74-2.42$ \\
6'-GL & $8.30 \pm 1.29$ & $5.95 \pm 0.72$ & $4.96 \pm 1.38$ & $4.17 \pm 1.54$ & $0.97-1.45$ \\
Total $^{*}$ & 14.81 & 12.20 & 11.18 & 10.86 & $9.97-13.46$ \\
\hline
\end{tabular}

Values are mean $\pm \mathrm{SD}(\mathrm{mg} / \mathrm{L}) .{ }^{*}$ The sum of the above oligosaccharides quantified in human milk in this study. ${ }^{* *}$ Values that converted into the $\mathrm{mg} / \mathrm{L}$ values reported by Kimura et al . (1997). ${ }^{10)}$

vine milk. Thus, there are differences in GL content between human and bovine milk.

A comparison of the present and previous data shows that, in human milk, the concentrations of GLs are much lower than those of 3-fucosyllactose, 2'-fucosyllactose, lacto- $N$-fucopentaose I, II and III, and $3^{\prime}-$ and $6^{\prime}-N$ acetylneuraminyllactose, etc. ${ }^{11,13)}$ At 10 days post partum, the concentrations of 3-fucosyllactose, 2'-fucosyllactose plus lacto- $N$-difucotetraose, lacto- $N$-fucopentaose I, lacto$N$-fucopentaose II plus lacto- $N$-difucohexaose II, lacto- $N$ fucopentaose III, $3^{\prime}-N$-acetylneuraminyllactose and $6^{\prime}-N$ acetylneuraminyllactose are 280.9, 685.5, 1137.5, 457.9, 71.6, 53.8 and $412.2 \mathrm{mg} / \mathrm{L}$, respectively, ${ }^{11,13)}$ while those of $3^{\prime}-\mathrm{GL}, 4^{\prime}-\mathrm{GL}$ and $6^{\prime}-\mathrm{GL}$ are $4.88,1.34$ and $4.96 \mathrm{mg} / \mathrm{L}$, respectively. It has been reported that some human milk oligosaccharides promote the growth of Bifidobacterium in intestinal tract of infants. ${ }^{14-17)}$ It is known, however, that the contents of such oligosaccharides are much lower in bovine than in human milk. The number of Bifidobacteria was found to be greater in the intestinal flora of breast-fed infants than in that of bottle-fed infants, ${ }^{18)}$ suggesting that this might be caused by the differences in the oligosaccharides content of human and bovine milk. It has been reported that the number of Bifidobacteria in the human intestine increases and the feces become soft following the administration of GOs manufactured from lactose using $\beta$-galactosidase. ${ }^{8)}$ It is therefore reasonable to suggest that GOs should be incorporated into infant formula, even though the GL contents are low in human milk, because it is not possible to obtain other human milk-type oligosaccharides at a reasonable cost.

It has been suggested, in addition, that the administration of GOs increases the absorption of sodium and magnesium in the cecum of rats. ${ }^{19)}$ It is thought that organic acids produced by fermentation of GOs by intestinal bacteria promote the solubilization of minerals and facilitates their absorption. This would provide another advantage of the incorporation of GOs into infant formula.

This study was supported by a grant from The 21 st Century COE Program (A-1), Ministry of Education, Culture, Sports, Science, and Technology, Japan.

\section{REFERENCES}

1 ) D.S. Newburg: Do the binding properties of oligosaccharides in human milk protect human infant from gastrointestinal bacteria ? J. Nutr., 127 (5 Suppl), 980s-984s (1997).
2 ) M. Rivero-Urgell and A. Santamaria-Orleans: Oligosaccharides: application in infant food. Early Hum. Dev., 65 Suppl, S43-S52 (2001).

3 ) J.R. Nesser, M. Golliard and S.D. Vedovo: Quantitative determination of complex carbohydrates in bovine milk and in milk-based infant formulas. J. Dairy Sci., 74, 2860-2871 (1991).

4 ) L.E. Wierzbicki and F.V. Kosikowski: Formation of oligosaccharides during $\beta$-galactosidase action on lactose. J. Dairy Sci., 56, 1400-1404 (1972).

5 ) T. Toba, Y. Tomita, T. Ito and S. Adachi: $\beta$-Galactosidases of lactic acid bacteria: Characterization by oligosaccharides formed during hydrolysis of lactose. J. Dairy Sci., 64, 185192 (1981).

6 ) N. Ohnishi, A. Yamashiro and K. Yokozeki: Production of galacto-oligosaccharide from lactose by Sterigmatomyces elviae CBS8119. Appl. Environ. Microbiol., 61, 4022-4025 (1995).

7 ) S. Yanahira, T. Kobayashi, T. Suguri, M. Nakakoshi, S. Miura, H. Ishikawa and I. Nakajima: Formation of oligosaccharides from lactose by Bacillus circulans $\beta$-galactosidase. Biosci. Biotechnol. Biochem., 59, 1021-1026 (1995).

8 ) M. Ito, Y. Deguchi, A. Miyamori, K. Matsumoto, H. Kikuchi, K. Matsumoto, Y. Kobayashi, T. Yajima and T. Kan: Effects of administration of galactooligosaccharides on the human faecal microflora, stool weight and abdominal sensation. Microb. Ecol. Health Dis., 3, 285-292 (1990).

9 ) G. Moro, I. Minoli, M. Mosca, S. Fanaro, J. Jelinek, B. Stahl and G. Boehm: Dosage-related bifidogenic effects of galactoand fructooligosaccharides in formula-fed term infants. J. Pediatr. Gastroenterol. Nutr., 34, 291-295 (2002).

10) K. Kimura, Y. Watanabe, K. Matsumoto and A. Miyagi: Studies on the natural galacto-oligosaccharide in commercial cow's milk. YAKULT Inst. Rep., 17, 1-7 (1997). (Japanese)

11) W. Sumiyoshi, T. Urashima, T. Nakamura, I. Arai, T. Saito, N. Tsumura, B. Wang, J. Brand-Miller, Y. Watanabe and K. Kimura: Determination of each neutral oligosaccharide in the milk of Japanese women during the course of lactation. Br. J. Nutr., 89, 61-69 (2003).

12) K. Kimura, K. Matsumoto, C. Ishihara, K. Harada and A. Miyagi: Structure determination of galacto-oligosaccharides by pyridylamination and NMR spectroscopy. Carbohydr. Res., 270, 33-42 (1995).

13) W. Sumiyoshi, T. Urashima, T. Nakamura, I. Arai, T. Nagasawa, T. Saito, N. Tsumura, B. Wang, J. Brand-Miller, Y. Watanabe and K. Kimura: Sialyl oligosaccharides in the milk of Japanese women: Changes in concentration during the course of lactation. J. Appl. Glycosci., 50, 461-467 (2003).

14) P. Gyorgy, R.F. Norris and C.S. Rose: Bifidus factor. I. A variant of Lactobacillus bifidus requiring a special growth factor. Arch. Biochem. Biophys., 48, 193-201 (1954).

15) P. McVeagh and J. Brand-Miller: Human milk oligosaccharides: Only the breast. J. Pediatr. Child. Health, 33, 281-286 (1997).

16) D.S. Newburg: Oligosaccharides in human milk and bacterial colonization. J. Pediatr. Gastroenterol. Nutr., 30, s8-s17 (2000).

17) T. Idota, H. Kawakami and I. Nakajima: Growth-promoting ef- 
fects of $\mathrm{N}$-acetylneuraminic acid-containing substances on Bifidobacteria. Biosci. Biotechnol. Biochem., 58, 1720-1722 (1994)

18) H. Yoshioka, K. Iseki and K. Fujita: Development and differences of intestinal flora in the neonatal period in breast-fed and bottle-fed infants. Pediatrics, 72, 317-321 (1983).

19) O. Chonan, R. Takahashi and M. Watanuki: Role of activity of gastrointestinal microflora in absorption of calcium and magnesium in rats fed $\beta 1-4$ linked galactooligosaccharides. Biosci. Biotechnol. Biochem., 65, 1872-1875 (2001).
3 種のヒトミルクガラクトシルラクトースの 各泌乳時期における経時的変動

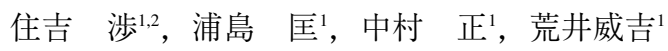
長澤孝志 ${ }^{3}$, 齋藤忠夫 ${ }^{4}$, 津村宣彦 ${ }^{5}$, Bing Wang ${ }^{6}$ Janette Brand-Miller ${ }^{6}$, 渡邊陽子 ${ }^{7}$ ，木村一雅 ${ }^{7}$

1 帯広畜産大学畜産学部

(080-8555 带広市稲田町西 2 線 11 番地 $)$

2 岩手大学大学院連合農学研究科

(020-8550 盛岡市上田 3-18-8)

3 岩手大学農学部

(020-8550 盛岡市上田 3-18-8)

${ }^{4}$ 東北大学大学院農学研究科

（981-8555 仙台市青葉区堤通雨宮町 1-1）

5 市立旭川病院産婦人科

(070-8610 旭川市金星町 1-1-65)

${ }^{6}$ シドニー大学生化学部門

(NSW, 2006, Sydney, Australia)

7 ヤクルト中央研究所中央分析室

（186-8650 国立市谷保 1796）

日本人女性の乳中に含まれる 3 種のガラクトシルラク トース $(\mathrm{GL})$ 濃度の泌乳期に伴う変動を，2-アミノピ リジル誘導体化を用いた順相系 HPLCにより定量した。 6'-GL 濃度は出産後 4 日目で最も高く, 泌乳期の経過に 伴って減少したのに対し，3'-GL および4'-GL 濃度は出 産後4 日目から100日目までほぼ変化がなかった。6' GL 濃度は出産後 4 日目のヒトミルクで主要な GL で あったが，牛乳では3'-GLが主要な GLであると報告さ れている。それらの濃度はヒトミルク中に含まれる2'フコシルラクトース, 3-フコシルラクトース, ラクト $-N-$ フコペンタオース I, II， II ならびに3'-抢よび 6'-N-ア セチルノイラミニルラクトース濃度に比べ，はるかに低 かった. 